IIIIIIIIIIIIIIIIIIIIIIIIIIIIIIIIIIII

Original Article

IIIIIIIIIIIIIIIIIIIIIIIIIIIIIIIIIII

\title{
Biodegradation of cyromazine by melamine-degrading bacteria
}

\author{
Takashi Hatakeyama, ${ }^{1}$ Kazuhiro Takagi ${ }^{1,2, *}$ and Koji Ito ${ }^{1,2}$ \\ ${ }^{1}$ Organochemicals Division, National Institute for Agro-Environmental Sciences, \\ 3-1-3 Kannondai, Tsukuba, Ibaraki, 305-8604, Japan \\ ${ }^{2}$ Department of Applied Biology and Chemistry, Graduate School of Agriculture, Tokyo University of Agriculture, \\ 1-1-1 Sakuragaoka, Setagaya-ku, Tokyo 156-8502, Japan
}

(Received June 12, 2015; Accepted September 20, 2015)

\begin{abstract}
Biodegradation of cyromazine was investigated in liquid cultures using three melamine-degrading bacteria Arthrobacter sp. MCO, Arthrobacter sp. CSP and Nocardioides sp. ATD6. Experiments were performed aerobically in a mineral medium with glucose as a carbon source and cyromazine as the sole nitrogen source. All three strains of bacteria degraded cyromazine. Cyromazine at $23 \mathrm{mg} / \mathrm{L}$ completely disappeared by Arthrobacter sp. MCO within 7 days. The bacterial density of all three strains increased with degradation of the cyromazine. The cyromazine metabolite $N$-cyclopropylammeline was detected and identified by ultra-performance liquid chromatography-tandem mass spectrometry (UPLC-MS/MS). This is the first report on the use of Arthrobacter sp. and Nocardioides sp. for cyromazine degradation and the occurrence of bacterial growth with cyromazine degradation. (c) Pesticide Science Society of Japan

Keywords: Bioremediation, Metabolite, $N$-cyclopropylammeline, Arthrobacter sp, Nocardioides sp, ultra performance liquid chromatography-tandem mass spectrometry.
\end{abstract}

Electronic supplementary materials: The online version of this article contains supplementary materials (Supplemental Figures S1, S2 and S3), which is available at http://www.jstage.jst.go.jp/browse/jpestics/.

\section{Introduction}

Cyromazine ( $N$-cyclopropyl-1,3,5-triazine-2,4,6-triamine) is an $s$-triazine pesticide used as an insect growth regulator for fly control on cattle manure, field crops, vegetables, and fruits. ${ }^{1,2)}$ Cyromazine is commonly added to poultry feed to control flies in the United States, and is also used with other animal species in other countries. In 2002, China's Ministry of 20 Agriculture approved cyromazine for use as a veterinary drug for animal breeding. Because the majority of cyromazine (75-86\%) is excreted through feces as the parent drug, ${ }^{3)}$ it is commonly added to animal feeds at levels of $0.5 \mathrm{mg} / \mathrm{kg}$ or higher to prevent fly larvae from hatching in manure. Although it has low toxicity for mammals, birds, fish, and bees, in edible poultry tissue, the tolerance for cyromazine is $0.05 \mathrm{mg} / \mathrm{kg}$. ${ }^{4)}$ The allowable concentrations of cyromazine in edible poultry tissue and milk products are $0.1 \mathrm{mg} / \mathrm{kg}$ and $0.01 \mathrm{mg} / \mathrm{kg}$, respectively, as set by the Codex Alimentarius Commission. ${ }^{5)}$ This is because cyromazine is metabolized via dealkylation reactions in both plants and animals to produce melamine. ${ }^{1,6-8)}$ Melamine and cyanuric acid, a metabolite of melamine, could combine to cause renal failure

\footnotetext{
* To whom correspondence should be addressed.

E-mail:ktakagi@niaes.affrc.go.jp

Published online January 6, 2016

(c) Pesticide Science Society of Japan
}

through the formation of insoluble melamine cyanurate crystal deposits in the kidneys. ${ }^{9)}$ An incident in 2007 that resulted in renal failure and death in cats and dogs was caused by adulteration of pet foods with melamine and cyanuric acid. ${ }^{10)}$ Therefore, melamine is on the Negative List for Non-edible Food Ingredients for Intentional Adulteration, and the allowable concentration of melamine in foods is $2.5 \mathrm{mg} / \mathrm{kg}$ as set by the US Food and Drug Administration and the European Union. ${ }^{11)}$ Moreover, the persistence of melamine in soil over a long time has been reported in Japan (http://www.maff.go.jp/j/syouan/nouan/ kome/k_hiryo/cacn_melamine/pdf/cacn_melamin_2504.pdf, accessed on March 20, 2015). During a recent Japanese academic conference, a few presentations featured cyromazine and its residual quantities and dissipation rates in poultry manure and its transfer to crops. ${ }^{12,13)}$

To counteract the risk posed by cyromazine as a contaminant, bioremediation is expected to be successful. In the past, Pseudomonas spp, ${ }^{14)}$ a mixture of Alcaligenes xyloxoxydans ssp. denitrificans, Sphingobacterium sp., and Pseudomonas sp, ${ }^{15)}$ and Comamonadaceae bacterium $\mathrm{CY} 1^{16)}$ have been reported to degrade cyromazine. These reports identified cyromazine metabolites with enzymes from $s$-triazine-degrading bacteria ${ }^{14)}$ and in living bacterial cells. ${ }^{15,16)}$ The above mixture of bacteria was shown to reduce the level of cyromazine from 10 to $8.5 \mathrm{mg} / \mathrm{L}$ in 10 days. ${ }^{15)}$ However, there have been no studies on the degradation of cyromazine with Arthrobacter sp. and Nocardioides sp. 
Three melamine degrading-bacteria available in our laboratory ${ }^{17,18)}$ can mineralize melamine via ammeline, ammelide and cyanuric acid. In this study, we investigated cyromazine degradation with these bacteria and identified the major metabolite produced by this degradation using ultra-performance liquid chromatography-tandem mass spectrometry (UPLC-MS/ MS).

\section{Materials and Methods}

\section{Chemicals and media}

Cyromazine (purity $>98 \%$ ) was purchased from Kanto Chemicals (Augsburg, Germany). Ammeline (purity >98\%) was purchased from Wako Pure Chemical Industries, Ltd. (Osaka, Japan). DAIGO R2A broth was purchased from Nihon Pharmaceutical Co., Ltd. (Tokyo, Japan). LB broth was prepared using $10 \mathrm{~g}$ of $\mathrm{NaCl}, 10 \mathrm{~g}$ of bactotrypton and $5 \mathrm{~g}$ of yeast extract in $1 \mathrm{~L}$ of Milli-Q water $(\mathrm{pH}=7.0)$. All other chemicals were obtained from Wako Pure Chemical Industries, Ltd. or Kanto Chemicals. Mineral medium was prepared by dispersing $10 \mathrm{~mL}$ of a trace element solution in $1 \mathrm{~L}$ of phosphate buffer $(\mathrm{PB})$. The trace element solution was prepared with $200 \mathrm{mg}$ of $\mathrm{FeSO}_{4} \cdot 7 \mathrm{H}_{2} \mathrm{O}, 10 \mathrm{mg}$ of $\mathrm{ZnSO}_{4} \cdot 7 \mathrm{H}_{2} \mathrm{O}, 5 \mathrm{mg}$ of $\mathrm{MnSO}_{4} \cdot \mathrm{H}_{2} \mathrm{O}, 30 \mathrm{mg}$ of $\mathrm{H}_{3} \mathrm{BO}_{3}, 24 \mathrm{mg}$ of $\mathrm{CoSO}_{4} \cdot 7 \mathrm{H}_{2} \mathrm{O}, 5 \mathrm{mg}$ of $\mathrm{CuSO}_{4} \cdot 5 \mathrm{H}_{2} \mathrm{O}, 5 \mathrm{mg}$ of $\mathrm{NiSO}_{4} \cdot 7 \mathrm{H}_{2} \mathrm{O}$, $5 \mathrm{mg}$ of $\mathrm{Na}_{2} \mathrm{MoO}_{4}$, and $50 \mathrm{mg}$ of $\mathrm{Ca}(\mathrm{OH})_{2}$ in $1 \mathrm{~L}$ of Milli-Q water. $\mathrm{PB}(\mathrm{pH}=6.8)$ was prepared using $1.2 \mathrm{~g}$ of $\mathrm{Na}_{2} \mathrm{HPO}_{4} \cdot 12 \mathrm{H}_{2} \mathrm{O}$ and $0.5 \mathrm{~g}$ of $\mathrm{KH}_{2} \mathrm{PO}_{4}$ in $1 \mathrm{~L}$ of Milli-Q water. The cyromazine degradation test broth was prepared with $1 \mathrm{~L}$ of mineral medium supplemented with $20 \mathrm{mg}$ of cyromazine and $1 \mathrm{~g}$ of glucose.

\section{Culture conditions}

Arthrobacter sp. MCO and Arthrobacter sp. CSP were incubated in R2A broth, and Nocardioides sp. ATD6 was incubated in 1/10 $\mathrm{LB}$ broth at $30^{\circ} \mathrm{C}$ with shaking at $180 \mathrm{rpm}$ for 1 day. A sterilized glycerol solution was added at a $10 \%$ volume fraction. The glycerol stocks were frozen and stored at $-80^{\circ} \mathrm{C}$.

\section{Cyromazine degradation}

The three bacterial strains from the glycerol stocks were preincubated in $\mathrm{R} 2 \mathrm{~A}$ or $1 / 10 \mathrm{LB}$ broth at $30^{\circ} \mathrm{C}$ with shaking at $180 \mathrm{rpm}$ for 1 day. Each culture broth was washed in $\mathrm{PB}$. The initial optical density of each bacterial inoculant at $600 \mathrm{~nm}$ was adjusted to about 0.05 in $5 \mathrm{~mL}$ of the cyromazine-degradation test broth and incubated at $30^{\circ} \mathrm{C}$ with shaking at $180 \mathrm{rpm}$. All samples were tested in triplicate and the results were averaged. As negative controls, cyromazine-free broth ( $1 \mathrm{~L}$ of mineral medium supplemented with $1 \mathrm{~g}$ of glucose) and a medium with an alternative nitrogen source ( $1 \mathrm{~L}$ of mineral medium supplemented with $50 \mathrm{mg}$ of $\left(\mathrm{NH}_{4}\right)_{2} \mathrm{SO}_{4}$ and $1 \mathrm{~g}$ of glucose) were also tested. After 4, 7 and 10 day, the cells were counted on R2A agar plates and the levels of cyromazine and its intermediates were measured by high performance liquid chromatography (HPLC).

\section{HPLC analysis of cyromazine}

The concentrations of cyromazine and its intermediate were measured by hydrophilic interaction chromatography. Because cyromazine is similar to melamine, the method used for analyzing melamine was used ${ }^{17)}$. Instruments included an in-line degasser, L-7100 pump, L-7200 auto sampler, L-7300 column oven, and L-7200 ultraviolet-visible (UV-Vis) detector (Hitachi, Tokyo Japan). Sample separation was performed on a hydrophilic interaction chromatography column (TSKgel Amide-80HR, $250 \mathrm{~mm} \times 4.6 \mathrm{~mm}$ i.d., $5-\mu \mathrm{m}$ particle size; Tosoh Corporation, Tokyo, Japan) at $40^{\circ} \mathrm{C}$. The mobile phase was $80: 20(\mathrm{v} / \mathrm{v})$ acetonitrile: $\mathrm{PB}\left(\mathrm{pH} 6.8,0.598 \mathrm{~g}\right.$ of $\mathrm{Na}_{2} \mathrm{HPO}_{4} \cdot 12 \mathrm{H}_{2} \mathrm{O} 0.598 \mathrm{~g}$ and $0.52 \mathrm{~g}$ of $\mathrm{NaH}_{2} \mathrm{PO}_{4} \cdot 2 \mathrm{H}_{2} \mathrm{O}$ in $1 \mathrm{~L}$ of Milli-Q water) with a flow rate of $1 \mathrm{~mL} / \mathrm{min}$. UV-Vis detection was performed at $214 \mathrm{~nm}$. The injection volume was $10 \mu \mathrm{L}$. Concentrations were quantified by the external standard method based on UV-Vis peak areas.

\section{UPLC-MS/MS}

The metabolite of cyromazine was identified using an ACQUITY UPLC system (Waters, Milford, MA) equipped with a Micromass Quattro micro API tandem quadrupole mass spectrometer (Waters). Separations were performed with an XBridge Amide column (Waters; $2.1 \times 150 \mathrm{~mm}, 3.5-\mu \mathrm{m}$ particle size) at $40^{\circ} \mathrm{C}$. The pump was operated in isocratic mode at a flow rate of $0.3 \mathrm{~mL} / \mathrm{min}$ using a mobile phase of acetonitrile and $100 \mathrm{mmol} / \mathrm{L}$ aqueous ammonium acetate $(90: 10, \mathrm{v} / \mathrm{v})$. The desolvation $\left(\mathrm{N}_{2}\right)$ and cone gas flow rates were 800 and $60 \mathrm{~L} / \mathrm{hr}$, respectively. Electrospray ionization (ESI)-MS analyses were performed with a nebulization flow rate of $50 \mathrm{~L} / \mathrm{hr}$ and a desolvation gas $\left(\mathrm{N}_{2}\right)$ flow rate of $800 \mathrm{~L} / \mathrm{hr}$. Source and desolvation temperatures were set at $120^{\circ} \mathrm{C}$ and $400^{\circ} \mathrm{C}$, respectively, and the capillary voltage was $3.5 \mathrm{kV}$. Mass spectrometric analyses of the compounds were performed with a Z-spray source using selected ion monitoring mode. The mass spectrum of cyromazine at $m / z 167[\mathrm{M}-\mathrm{H}]^{-}$was obtained using a cone voltage of $30 \mathrm{~V}$ in positive ion mode. For unknown metabolites, total ion chromatography (TIC) mode was used in negative and positive ion modes over the mass range $m / z 30-500$. For tandem mass spectrometry analyses, the collision gas was argon (purity 99.999\%, Japan Fine Products Co., Ltd., Kanagawa, Japan) with a pressure of $4.58 \times 10^{-3} \mathrm{mbar}$ in the collision cell. The other measurement conditions were the same as for the ESI-MS analyses. The UPLC-ESI-MS and UPLC-ESI-MS/MS systems were controlled using MassLynx NT v 4.1 software (Waters).

\section{Results}

\section{Degradation of cyromazine by Arthrobacter spp. and Nocardi-} oides sp. ATD6

The initial concentration of cyromazine in the aerobic culture was $23.3 \mathrm{mg} / \mathrm{L}$. With Arthrobacter sp. MCO, cyromazine was not detectable after 7 days of incubation (Fig. 1). By contrast, with the other two strains, approximately $5 \mathrm{mg} / \mathrm{L}$ of cyromazine remained in the culture after incubation for 7 days. After 10 day, cyromazine had almost disappeared by Arthrobacter sp. CSP $(<0.1 \mathrm{mg} / \mathrm{L})$, however, approximately $1 \mathrm{mg} / \mathrm{L}$ of cyromazine still remained with Nocardioides sp. ATD6. As the cyromazine con- 


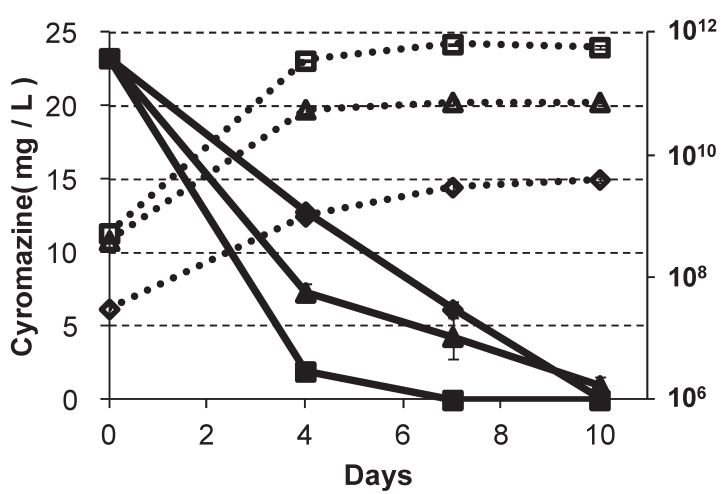

Fig. 1. Degradation of cyromazine by the bacterial strains MCO, CSP and ATD6. Changes in the concentration of cyromazine (solid line) with MCO (squares), CSP (diamonds) and ATD6 (triangles) and bacterial density (dotted line) are shown as the mean value of triplicate experiments. Error bars indicate standard deviations.

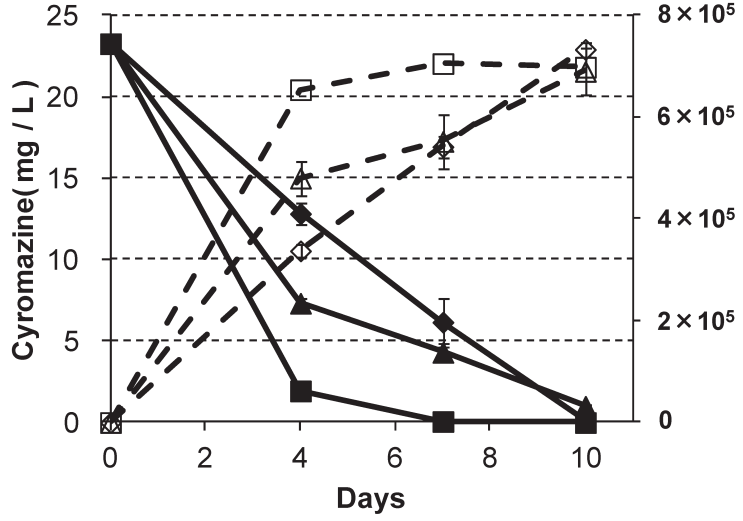

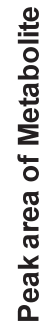

Fig. 2. Degradation of cyromazine and metabolite production with the bacterial strains MCO, CSP and ATD6. Changes in the cyromazine concentration (solid line) with MCO (solid squares), CSP (solid diamonds) and ATD6 (solid triangles) and that of the metabolite (dotted line) with MCO (open squares), CSP (open diamonds) and ATD6 (open triangles) are shown as the mean value of triplicate experiments. Error bars indicate standard deviations.

\section{(A)}

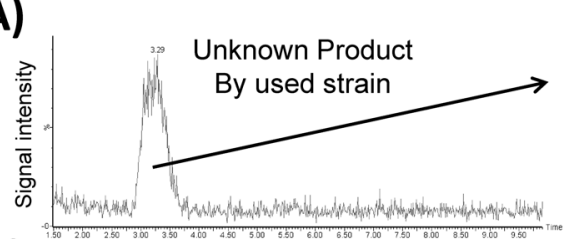

(B)

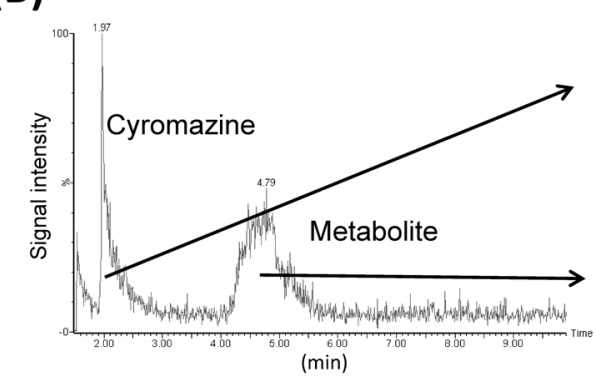

(C)

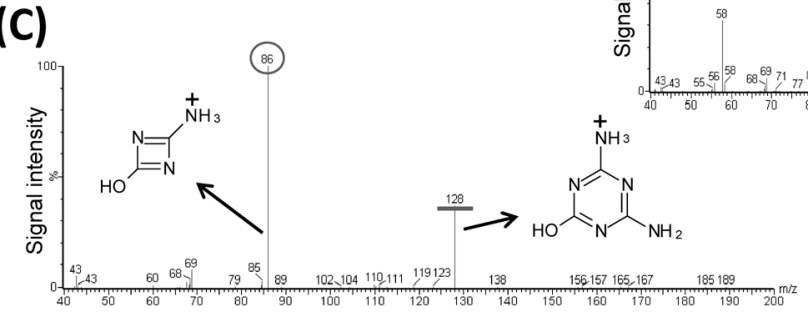

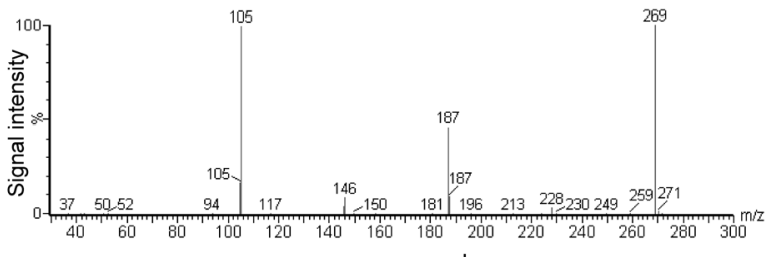
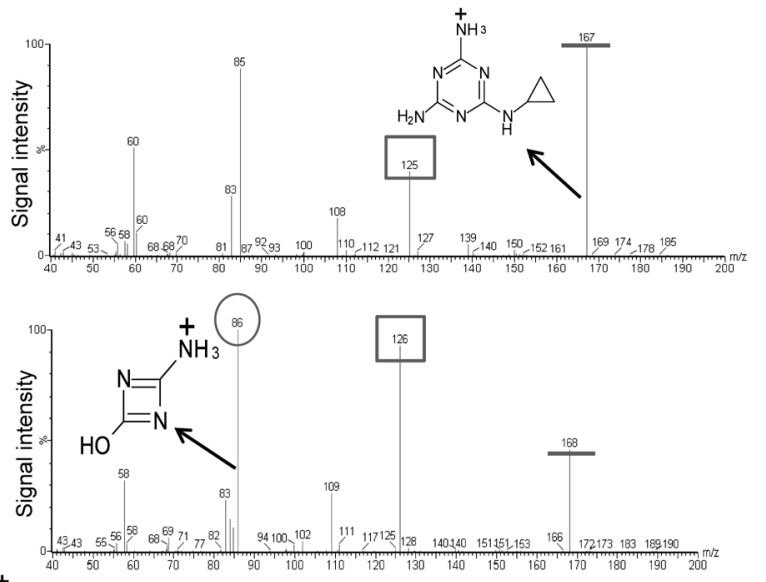

Fig. 3. The UPLC-MS chromatograms and UPLC-MS/MS fragmentation patterns. A sample of the unknown metabolite was obtained from the cyromazine-degradation broth after 4 day with the MCO strain. (A) Chromatogram and fragmentation pattern of the negative control without cyromazine. (B) Chromatogram and fragmentation patterns for cyromazine and the metabolite. (C) Fragmentation pattern for ammeline.

centration decreased, the bacterial density gradually increased for all three strains (Fig. 1). Meanwhile, less bacterial density for all three strains was observed in the cyromazine-free broth than in the cyromazine-degradation test broth (Supplemental Fig. S1).

\section{Detection of cyromazine-degradation metabolites}

All three bacteria resulted in cyromazine degradation of an unknown metabolite, the content of which gradually increased over time (Fig. 2). After 10 days, cyromazine had almost disappeared with all three strains $(<1 \mathrm{mg} / \mathrm{L}$ remained), and the unknown metabolite's peak was a similar in size for all three 
strains. Melamine was not detected in the cyromazine-degradation test. When growth of the three strains was investigated in the medium with an alternative nitrogen source $(50 \mathrm{mg} / \mathrm{L}$ $\left.\left(\mathrm{NH}_{4}\right)_{2} \mathrm{SO}_{4}\right)$, more growth occurred as compared with that in the cyromazine-free broth. However, no peak was detected by HPLC (Supplemental Fig. S2).

3. Identification of the major metabolite of cyromazine by UPLC-ESI-MS

A sample taken after 4 days of degradation with the MCO strain was investigated by UPLC-ESI-MS. In the cyromazine-degradation test broth, a peak for the unknown metabolite was detected at $4.79 \mathrm{~min}$ (Fig. 3B). In contrast, the alternative nitrogen source negative control showed an unknown peak at $3.39 \mathrm{~min}$ but no peak was detected for the cyromazine metabolite (Fig. $3 \mathrm{~A})$. The retention time of the unknown compound at $4.79 \mathrm{~min}$ was longer than that of cyromazine. This peak had an $\mathrm{m} / \mathrm{z}$ ratio of 168 in TIC (+) mode. The peaks observed for the unknown metabolite with the other strains also gave similar UPLC-ESIMS results.

4. Characterization of the cyromazine metabolite by UPLC-ESIMS-MS

The unknown metabolite of cyromazine (Fig. 3B) was identified by its fragmentation pattern using the major product ions at $\mathrm{m} / z 86$ and 126 in TIC (+) mode. The product ion at $\mathrm{m} / z 86$ was consistent with that of the product ion of ammeline (Fig. 3C). The product ion at $m / z 126$ from the unknown metabolite corresponded to a cyromazine product ion $(\mathrm{m} / \mathrm{z} 125)$.

\section{Discussion}

The results of the cyromazine-degradation test (Fig. 1) indicated that all three bacterial strains could degrade cyromazine. Although earlier studies reported five other bacterial genera that can degrade cyromazine, ${ }^{14-16)}$ this is the first report of cyromazine degradation with Arthrobacter sp. and Nocardioides

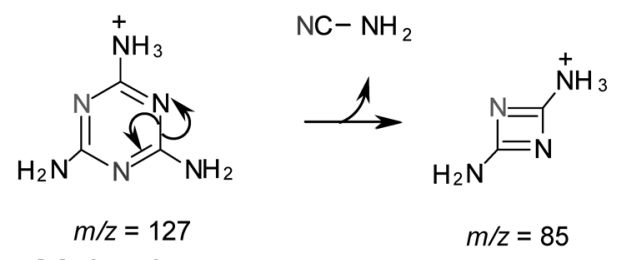

Melamine

P. Varelis and R. Jeskelis, 2008, Food Addit. Contam. Part A Chem. Anal. Control Expo. Risk Assess ${ }^{22)}$.

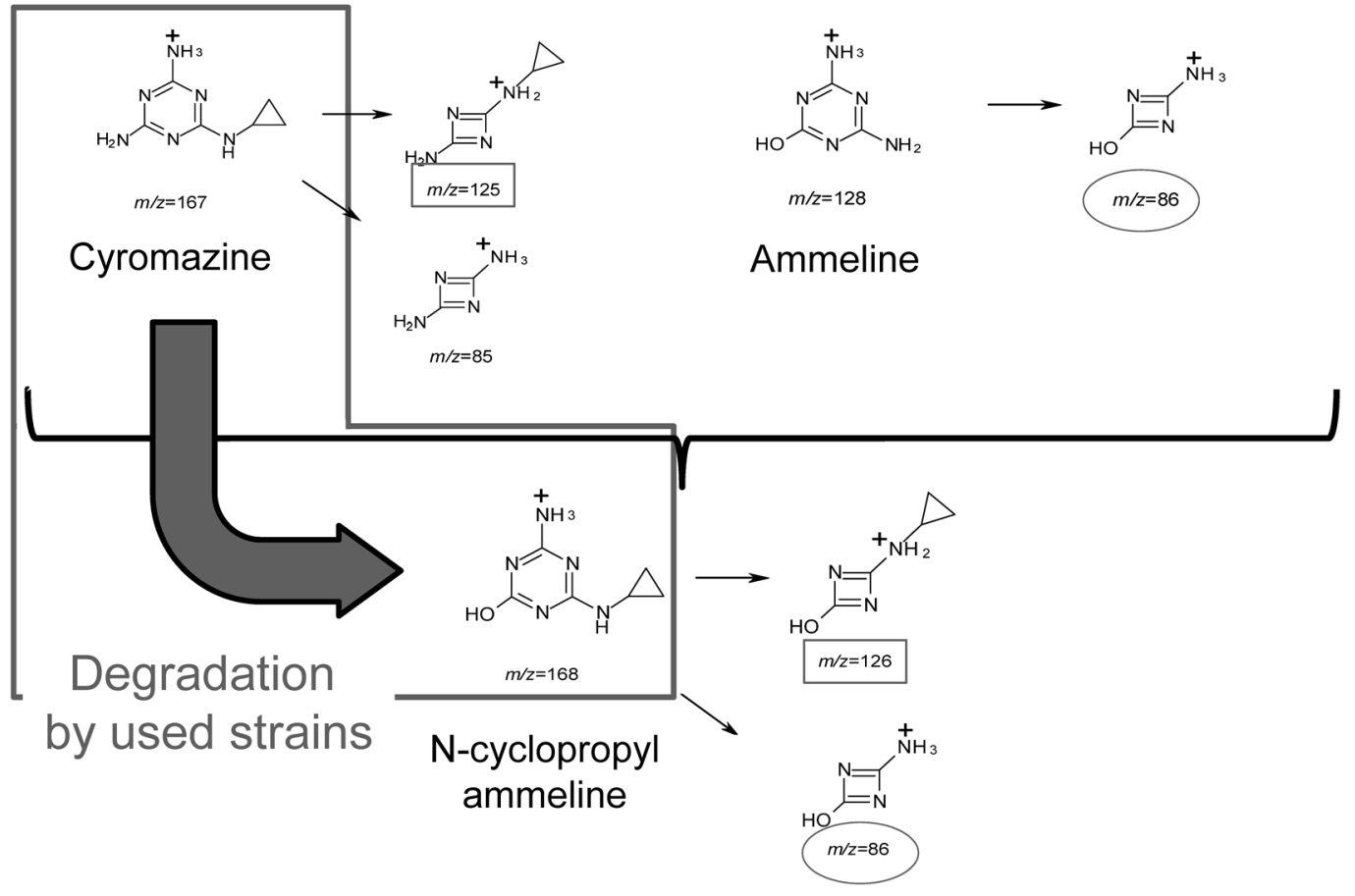

Fig. 4. Identification of the metabolite of cyromazine based on the fragmentation patterns of cyromazine, ammeline and reported fragmentation patterns of melamine and cyanuric acid. 
sp. Moreover, this is the first report of bacterial growth with cyromazine degradation. Bacterial growth with cyromazine degradation occurred as the bacteria used cyromazine as a nitrogen source. Compared to the cyromazine degradation rate (10 to $8.5 \mathrm{mg} / \mathrm{L}$ in 10 days) reported for a bacterial mix in an earlier study, $\left.{ }^{15}\right)$ the cyromazine-degradation rate $(23 \mathrm{mg} / \mathrm{L}$ in 10 days $)$ in the current study was higher; this was true for all bacterial strains tested. Arthrobacter sp. MCO was especially efficient; cyromazine $(23 \mathrm{mg} / \mathrm{L})$ completely disappeared within 7 days. Other earlier reports on cyromazine degradation ${ }^{13,16)}$ have not provided degradation rates. In the present study, the cyromazine concentration gradually decreased and the concentration of an unknown metabolite gradually increased rather than decreasing during degradation (Fig. 2). Therefore, we determined that cyromazine degradation had stopped. This metabolite was characterized by UPLC-ESI-MS and had an $\mathrm{m} / z$ value of 168 in TIC (+) mode. This indicated a molecular weight of 167 for the unknown compound. The unknown metabolite was then identified by UPLC-MS/MS. The fragmentation pattern of the unknown metabolite (Fig. 3B) identified the product ion at $\mathrm{m} / \mathrm{z} 86$ as 2-amino-4-hydroxy-1,3-diazete; this product ion is found with ammeline (Fig. 3C). In the fragmentation patterns of melamine and cyanuric acid ${ }^{22)}$ (Fig. 4), product ions are observed at $\mathrm{m} / \mathrm{z}$ 125 for 2-cycloprorylamino-4-amino-1,3-diazete and at $\mathrm{m} / \mathrm{z}$ 126 for 2-cycloprorylamino-4-hydroxy-1,3-diazete, respectively. Therefore, the fragmentation pattern for the unknown metabolite was consistent with the structures of ammeline and the cyclopropyl group. In consideration of the cyromazine metabolic pathway $^{14)}$ and the mineralization pathway of melamine proceeding via ammeline, ${ }^{17)}$ the unknown metabolite was identified as $\mathrm{N}$-cyclopropylammeline (2-amino-4-(cyclopropylamino)6-hydroxy-1,3,5-triazine). This is the first regarding the fragmentation pattern of $\mathrm{N}$-cyclopropylammeline. This method of identifying the unknown compound using the fragmentation patterns of similar compounds rather than standards is novel. In reference to the cyromazine metabolic pathway, ${ }^{14)} \mathrm{N}$-cyclopropylammeline is the initial metabolite. Moreover, the area of the unknown peak produced with Arthrobacter sp. MCO stayed constant from day 7 to day 10 , and no new peaks were detected during this time (Fig. 1). With the alternative nitrogen source negative control (Fig. 3A), the retention time of the unknown peak was different from that of the cyromazine metabolite $(\mathrm{N}$ cyclopropylammeline, Fig. 3B). Moreover, this peak was not detected by HPLC (Supplemental Fig. S2). Therefore, this product appears to be a metabolite of $\left(\mathrm{NH}_{4}\right)_{2} \mathrm{SO}_{4}$ produced by the bacterial strains. However, this product could not be identified, even after detailed tests. Therefore, $N$-cyclopropylammeline was the only metabolite produced from cyromazine by the bacterial strains used in our study. Although we investigated several other degradation conditions, further degradation using these strains was not possible. In both plants and animals, cyromazine forms melamine after metabolism via dealkylation reactions and after environmental degradation. ${ }^{19-21)}$ However, melamine is not produced from $\mathrm{N}$-cyclopropylammeline. Moreover, even if amme- line was produced from $\mathrm{N}$-cyclopropylammeline under biological or environmental conditions, we confirmed that the bacterial strains investigated could also degrade ammeline (Supplemental Fig. S3). Therefore, the bacterial strains degraded cyromazine and did not produce melamine. Recently, many studies on cyromazine have focused on the risk of contamination from cyromazine and melamine. ${ }^{12,13)}$ We expect that the strains studied in this research will be effective for the bioremediation of cyromazine and melamine.

\section{References}

1) R. A. Yokley, L. C. Mayer, R. Rezaaiyan, M. E. Manuli and M. W. Cheung: J. Agric. Food Chem. 48, 3352-3358 (2000).

2) A. A. Assar, M. M. Abo-El-Mahasen, N. M. Harba and A. A. Rady: J. Am. Sci. 8, 443-450 (2012).

3) J. Keiding: Bull. Entomol. Res. 89, S1-S67 (1999).

4) US FDA: Tolerances for residues of new animal drugs in food. 21, Code of Federal Regulations 556.67, 460-491 (1987).

5) Codex Alimentarius Commission: Updated as at the 35th Session of the Codex Alimentarius Commission (2012).

6) A. M. Cook and R. Hutter: J. Agric. Food Chem. 29, 1135-1143 (1981).

7) G. Goutailler, J.-C. Valette, C. Guillard, O. Paıssé and R. Faure: J. Photochem. Photobiol. Chem. 141, 79-84 (2001).

8) J. V. Sancho, M. Ibanez, S. Grimalt, O. J. Pozo and F. Hernandez: Anal. Chim. Acta 530, 237-243 (2005).

9) P.-C. Wang, R.-J. Lee, C.-Y. Chen, C.-C. Chou and M.-R. Lee: Anal. Chim. Acta 752, 78-86 (2012).

10) C. A. Brown, K.-S. Jeong, R. H. Poppenga, B. Puschner, D. M. Miller, A. E. Ellis, K.-I. Kang, S. Sum, A. M. Cistola and S. A. Brown: J. Vet. Diagn. Invest. 19, 525-531 (2007).

11) http://www.fda.gov/NewsEvents/PublicHealthFocus/ucm 179005. $\mathrm{htm} /$ (Accessed 2015/09/24)

12) N. Usui, M. Oohara, K. Takahashi, I. Uchida, M. Ito, Y. Aoki, Y. Ito and N. Hirayama: Abstr. 129th Annu. Meeting Pharm. Soc. Jpn., 26Q-pm188 (2009) (in Japanese).

13) J. Kohama, I. Uchida, A. Nakada, H. Kobayashi, K. Takahashi, Y. Aoki and N. Hirayama: Abstr. 130th Annu. Meeting Pharm. Soc. Jpn., 30P-pm359 (2010) (in Japanese).

14) A. M. Cook, H. Grossenbacher and R. Hütter: Biochem. J. 222, 315320 (1984).

15) C. Y. Kontchou and N. Gschwind: Ecotoxicol. Environ. Saf. 43, 47-56 (1999).

16) H. Wang, C. Geng, J. Li, A. Hu and C. Yu: Appl. Microbiol. Biotechnol. 98, 3287-3293 (2014).

17) K. Takagi, K. Fujii, K. Yamazaki, N. Harada and A. Iwasaki: Appl. Microbiol. Biotechnol. 94, 1647-1656 (2012).

18) T. Hatakeyama, K. Takagi, K. Yamazaki, F. Sakakibara, K. Ito, E. Takasu, T. Naokawa and K. Fujii: World J. Microbiol. Biotechnol. 31, 785-793 (2015).

19) R. A. Yokley, L. C. Mayer, R. Rezaaiyan, M. E. Manuli and M. W. Cheung: J. Agric. Food Chem. 48, 3352-3358 (2000).

20) G. Goutailler, J.-C. Valette, C. Guillard, O. Parssé and R. Faure: J. Photochem. Photobiol. Chem. 141, 79-84 (2001).

21) J. V. Sancho, M. Ibanez, S. Grimalt, O. J. Pozo and F. Hernandez: Anal. Chim. Acta 530, 237-243 (2005).

22) P. Varelis and R. Jeskelis: Food Addit. Contam. Part A. Chem. Anal. Control Expo. Risk Assess. 25, 1208-1215 (2008). 